\title{
Knowledge Economy and the Two New Resources: Education and Research
}

\author{
Gabriela Arionesei $^{1}$, Daniela-Giconda Burac ${ }^{1}$, Daniela-Mihaela Neamtu ${ }^{1}$, \\ Livia-Elena Vranciu ${ }^{1}$ \\ ${ }^{1}$ Stefan cel Mare University of Suceava, Romania
}

\begin{abstract}
"Lisbon Treaty" approaches knowledge society as a powerful goal for the European Union. In this article, we will try to achieve the recognition of the role of education, as a main pillar in building a European area of knowledge, learning and research system, as inputs. It is required a broader vision over the educational process, placed in a more dynamic world, which may be able to face the present and the future.

In the world of the new technology, education will have the main role in creating the new way of life specific to a society based on knowledge and learning. In conclusion, one can say that this authentic industry underlies the economic development, through the industrial progress intake necessary knowledge and the training of the qualified personnel that performs the economic program.
\end{abstract}

Keywords: creativity, economy, education, knowledge, research.

\section{Introduction}

The New Europe, whose core is formed by The European Union, is facing today by unprecedented challenge: competition, in all areas and at all levels, with the world powers, but also with developing countries, especially in Asia, which comes with a great human and economic potential.
Knowledge and research have a fundamental role to play in the contemporary world scene. European leaders concluded that, in order to be globally competitive, Europe must build a society and an economy based on knowledge. The institution, around which we build the new society, is Education. Globalization means competition in areas such as economic and financial power, but also in knowledge. However, knowledge is the result of two fundamental processes of human evolution and society: education and research.

Education is creating appropriate conditions for development and application of knowledge. But education has and must have a privileged situation, but also full of responsibilities in relation to the research factor.

\section{Knowledge-based Economy and Knowledge Management}

Human life is dominated by the spirit of creativity and it evolves in this spirit. Today mankind has reached such a stage of development, possible for the existence of a new type of economy.

We all speak about an economy based on knowledge and ideas, in which the key factor of prosperity and creating jobs is the degree of implementation, of innovation and new technologies in all economic areas of society.

Peter Drucker [1] is in the top of management specialists who stressed the importance of orientation to knowledge seen 
as a basic resource, emphasizing that the only advantage you can have is the company's ability to exploit the knowledge obtained by anyone, anywhere.

There are mixed approaches of the knowledge management in some works: Malhotra [2] (1997, 2004, 2005), in which he considered that knowledge management provides the necessary elements for survival and competence of organizations to cope with changes in the business environment, research and development of the management: Harrison [3] 2000, creativity management: Mumford [4] 2000, creating the conditions for innovation: Nonaka [5] 1991.

\section{Education and Creativity for a Knowledge -based Society}

In this context, education is the foundation of a society for the future, and knowledge is the main component of the economic and social development.

Education and training produce economic and social benefits, so education will have an essential role in creating new specific lifestyle of a society based on knowledge and learning.

It is a fact that a primary resource of tomorrow's world will be knowledge and that people of the future will be - as stated P. Drucker [6]: "knowledge workers and services providers, trained and educated in consonance with the performance criteria of society, able to incorporate attitudes and behavior to their values, to behave as educated persons, able to influence the knowledge and skills of the present and modeling the future. They are ready to live in a global world".

An essential element of the education system is creativity. The creative role of education cannot be understood only by creating and fostering innovative capabilities of personality: "micro-creativity", but also through mutations that schools can and must produce in global society: "macro-creativity".

\section{Education, Manufacturing, Re- search}

Edward F. Denison [7], basing on a historical analysis of the period 1929-1969, makes appraisals over the influences of various growth factors and production improvements. He has the idea of considering qualitative changes occurring in workforce training.

One of the first works in which the educational system is analyzed from an economic perspective, the relationship between science, education and production occurs in 1972 and belongs to J.L. Maunouri [8]. It lists eleven correlations:

1. Scientific research increases the knowledge background available to mankind.

2. The production has its subproducts as new information added to the acquisition of knowledge.

3. Existing knowledge are exploited in the production process.

4. Scientific activity is carried out based on the existing knowledge.

5. Knowledge is transmitted by the educational system.

6. Education forms the researchers.

7. Education forms suitable skilled labor for production.

8. Labor can always be brought back in the re-education system.

9. The production itself forms the skilled labor.

10. Researchers improve their qualifications and skills in the scientific activity.

11. Production activity controls the research sector, services, and this result in economic value.

What fundamentally unites the three subsystems: production, education and research is the triple process of innova- 
tion, forming and circulation of knowledge.

\subsection{Methods and Modern Techniques in Education}

The key word is modernization, understood as a permanent action for adequacy education, methods and educational technology, at a development level of science and technology. Innovation of education is a complex process targeting a decisive improvement of the educational system, performed on stages, its effectiveness being determined by a number of factors presented in the following scheme:

\begin{tabular}{|c|c|}
\hline $\begin{array}{c}\text { Innovation pro- } \\
\text { cess }\end{array}$ & $\begin{array}{c}\text { Factors that re- } \\
\text { sult in the context } \\
\text { of innovation: }\end{array}$ \\
\hline $\begin{array}{c}\text { Launching } \\
\text { Planning }\end{array}$ & $\begin{array}{l}\text {-political; } \\
\text {-financing; } \\
\text {-management } \\
\text {-leadership, } \\
\text {-research, } \\
\text {-training, } \\
\text {-attitude; } \\
\text {-information; } \\
\text {-stakeholders; } \\
\text { Construction }\end{array}$ \\
\hline Experimentation & \\
\hline Evalution & \\
\hline Revision & \\
\hline Dissemination
\end{tabular}

Fig. 1: Education innovation. The Fundamentals of Educational Planning, UNESCO

School should become a research laboratory in which the student comes to make discoveries. Teaching the child, as emphasized P. P. Bolonski, does not mean to give him our truth, but to develop his own thinking, to help him understand the sensitive world, immediately obvious.

Another important and efficient method would be a proper organization of student's activities by developing teaching strategies having as fundamental objec- tives setting in the school a genuine intellectual climate. Dewey J. observes that every lesson should be an answer for the science and student's questions. The teacher must guide and control not only the quantity and quality of assimilated knowledge, but the ways to reach them.

Modernization of teaching and didactic technology has an essential aspect: full assimilation and the use of educational techniques, new communication techniques that our century offers us.

\subsection{Results and Discussions}

Taking into consideration the conditions of our society, modernization of education itself becomes one of the essential instruments of social change, being the effect of school planning, as a mediator between social and economic legislation mutations.

\begin{tabular}{|c|c|}
\hline \multicolumn{2}{|c|}{ Society } \\
\hline $\begin{array}{l}\text { Changing } \\
++ \text { (ideal type 1) } \\
\text { - Non- } \\
\text { contradictory re- } \\
\text { port: congruence } \\
\text { between school } \\
\text { and changes in } \\
\text { society. }\end{array}$ & $\begin{array}{l}\text { Unchanging } \\
+ \text { - (ideal type } 2 \text { ) } \\
\text { - Contradictory re- } \\
\text { port: changes in } \\
\text { school provided by a } \\
\text { society that does not } \\
\text { change. }\end{array}$ \\
\hline $\begin{array}{l}-+(\text { ideal type } 3) \\
- \text { The existence of } \\
\text { contradictory } \\
\text { changes in society } \\
\text { which does not } \\
\text { meet changes in } \\
\text { school. }\end{array}$ & $\begin{array}{l}\text { - - (ideal type } 4) \\
\text { - Contradictory re- } \\
\text { port: the conserva- } \\
\text { tive correspondence, } \\
\text { both of the school } \\
\text { and the society. }\end{array}$ \\
\hline
\end{tabular}

"Macro-creativity", meaning social innovation of learning, has the best conditions for affirmation in type 1 , and can occur, but contradictorily in type 2 . It is obvious that the best type is the promotion of "micro-creativity", congruent with 
the "macro-creation" function of education, in which pedagogic innovation, referred to a teacher-student relationship, aims to stimulate individual creativity blended with social changes function as a whole and in its relations with macrosocial structures.

The function of social innovation requires school education and its relationship with society generates types of knowledge, skills and behaviors, training individual and collective subjects to initiate and participate in social change [9].

To ensure a balanced development of the education system, any development strategy must be put into two essential perspectives: the socio-economic and individual one [10].

\section{Conclusions}

The whole content of this material has developed scientifically an argument based on the current needs and practical possibilities for investigating the link between education, learning and knowledge-based economy.

In conclusion, education can accelerate the progressive growth rate of the economy. In this context, organizations are becoming more interested in knowledge, seen as a resource in providing survival and development in an environment where the selection criterion is the economic efficiency. To be competitive, organizations encourage learning at all levels. Education can bring people not only the best technological knowledge, but, by training, the innovative potential which can lead to an advance of knowledge and also contributes to economic growth.

The education and research are considered major resources of the development.
Creativity is recognized as an essential purpose of learning, education, both in terms of increasing the impact of its product renewal: people as active participants in the development and training, in a conscious and active perspective for the spiritual and material progress.

\section{References}

[1] Drucker, P. "The Coming of the New Organization", in Harvard Business Review, pp. 66-71, 1988.

[2] Malhotra, Y. "Integrating Knowledge Management", 2005. www.Kmnetwork.com/Km.htm

[3] Harrison, S.J. "Managing Know-Who Based Companies. A Multi - Networked Approach to Knowledge and Innovation Management", Cheltenham, 2000.

[4] Mumford, M.D. "Managing creative people: Strategies and tactics for innovation", in Human Resource Management Review 10(3), 2000.

[5] Nonaka, I., "The Knowledge Creating Company", in Harvard Business Review, 1991.

[6] Drucker, P., "The New Society of Organization", in Harvard Business Review, nr. 70(5), 1992.

[7] Denison, F.E., "The Sources of Economic Growth in the U.S. and Alternatives before Us", New York, 1962.

[8] Maunouri, L.J. "Economie du savoir", Paris, 1972.

[9] Păun, E., "Educaţia şi rolul ei în dezvoltarea social-economică", Editura Didactică şi Pedagogică, Bucureşti, 1974.

[10]Vlăsceanu, L. "Învăţământ, producţie, cercetare”, E.D.P., Bucureşti,1972. 